\title{
Isolation, identifications and antimicrobial susceptibility pattern of coagulase positive Staphylococcus from subclinical mastitic dairy cattle in and around Haramaya University
}

\author{
Firaol Tafa', Yitagele Terefe ${ }^{* 1}$, Nateneal Tamerat ${ }^{1}$, Endrias Zewdu ${ }^{2}$ \\ ${ }^{1}$ Haramaya University, College of Veterinary Medicine, P.O.BOX 138, Dire Dawa, Ethiopia \\ ${ }^{2}$ Ambo University, College of Agriculture and Veterinary Sciences, Department of Veterinary \\ Laboratory Technology, P.O.Box 19, Ambo, Ethiopia \\ ${ }^{*}$ Corresponding author ; E-mail:yitagele@yahoo.com/yterefe@haramaya.edu.et
}

\section{Abstract}

A cross-sectional study was conducted from November 2013 to April 2014 to isolate coagulase positive Staphylococcus (CPS) from subclinical mastitic (SCM) lactating cows, to establishing prevalence, to identify risk factors and to determine the antimicrobial susceptibility pattern of CPS isolates in and around Haramaya University, Eastern Ethiopia. A semi-structured questionnaire survey, California mastitis test (CMT), bacterial isolation and identification and in vitro antimicrobial susceptibility tests were conducted during the study. A total of 210 dairy cattle from seven farms were screened for SCM by CMT. The prevalence of SCM in the study areas was $71.4 \%(150 / 210)$. Milk samples were collected from 562 quarters of 150 cows free of clinical mastitis but positive in CMT. Among these cows 38 of them had blind quarters (6.76\%). The prevalence of CPS was found to be $66.0 \%(99 / 150)$ and $28.46 \%(160 / 562)$ on animal and quarter basis, respectively. Among the risk factors studied, SCM due to CPS was significantly higher $(P>0.05)$ in older cows $(100 \%)$ than younger $(70.0 \%)$, in cows during late lactation $(96.3 \%)$, in cows which gave more than 5 births (100\%), in cross-breed cows $(71.2 \%)$ than local breed cows $(54.3 \%)$, in cows with udder / teat injuries (96.3\%) and in cows managed under poor house hygiene (82.5\%). Antimicrobial susceptibility testing of 9 antibiotics carried out using Kirby-Bauer disc diffusion method and revealed high multidrug resistance of $71(87.6 \%)$. High level of resistance to common drugs like ampicillin (90.1\%), penicillin (67.9\%), and tetracycline (54.3\%) was registered. In contrast, the CPS isolates were susceptibility for chloramphenicol, gentamycin and kanamycin at $63 \%, 46.9 \%$, and $41.97 \%$, respectively. In conclusion, the study confirms the importance of CPS as a mastitis causing multidrug resistant bacterium. Therefore, improved management and early treatment of SCM cases with drug of choice is imperative to tackle CPS mastitis.

Keywords: Antimicrobial susceptibility, Coagulase positive Staphylococcus, and risk factors.

http://dx.doi.org/10.4314/evj.v19i2.8 


\section{Introduction}

Mastitis is an inflammation of the parenchyma of mammary gland that causes physical and chemical changes in milk and leads to pathological condition of the glandular tissue (Ranjan et al., 2011). The majority cases of mastitis are caused by bacteria (Radostits et al., 2007). Mastitis is an important disease of dairy animals and the huge bottleneck, impacting the milk production of Ethiopian diary sector (Demelash Biffa et al., 2005). It is generally associated with poor hygienic husbandry practices, bruising of mammary tissue or other wound predisposes the cow to mastitis while the primary reservoir of contagious pathogens is the mammary gland itself (Hunderra Sori et al., 2005).

In sub clinical mastitis, there is no visible appearance of changes in the milk or udder, but milk production decreases and composition is altered due to bacteria presence. SCM is 3 to 4 times more common than the clinical mastitis and it is not often detected by most of the dairy farmers; hence it is the major factor affecting the productivity of dairy cattle (Mungube et al., 2005). Reduction in milk production and quality, treatment cost, premature culling of cows and loss of genetic potential will follow leading to heavy economic losses (Leitner et al., 2011). Furthermore, it has zoonotic importance since the affected cows have bacteria contaminated milk (Sharif et al., 2009).

Among the various bacterial pathogens, staphylococcus has been reported as the major cause SCM (Kassaye Getahun et al., 2008). The most widely used and generally accepted criterion for identification of pathogenic staphylococci is usually by their ability to produce coagulase due to the fact that coagulase tests correlates well with staphylococcus species pathogenicity (Lamprell et al., 2004). On the other hand, antimicrobial therapy plays a great role in the control of bovine mastitis caused by staphylococcus species. In fact, Microbial identification and susceptibility reports as a means to guide veterinarians for initial therapeutic decisions have paramount importance. Unfortunately, antimicrobial resistance has become a growing concern worldwide. Thus, generation of antimicrobial resistance data is essential for interventions and monitoring of antimicrobial resistance (Basappa et al., 2011).

In Eastern Ethiopia, specifically around Haramaya University small holder dairy development activities are expanding in non-organized manner due to the increasing demand for milk. However, there is a growing production inefficiency posed by health constraints including drug resistances. This is 
partly due to the fact that very limited research was employed to address the issue in the area. Therefore, the present work was undertaken with the objectives of isolation and determination of in vitro antimicrobial susceptibility pattern of CPS, in addition to assessment of potential risk factors relation to CPS prevalence in the study area.

\section{Material and Methods}

\section{Study area}

The study was conducted in dairy farms in and around Haramaya district including Haramaya University and Harar city, Eastern Ethiopia. The elevation of study areas is about $2000 \mathrm{~m}$ above sea level. It has mean annual temperature and relative humidity of $18^{\circ} \mathrm{C}$ and $65 \%$, respectively. It receives an average rain fall of approximately $900 \mathrm{~mm}$. Animal production is undergone with agricultural activities side by side (HADB, 2009).

\section{Study design and Study animal}

In the cross-sectional study lactating cows were considered for the presence of sub clinical mastitis. The study animals are both cross and local breed lactating cows. The local dairy cows are managed mainly under traditional extensive husbandry system; while most of the cross bred cows are often managed under a small-scale semi-intensive management system.

\section{Sampling Method}

The study was carried out in seven farms with different herd sizes ranging from 12 to 60 animals. The sampling of the farm was employed purposively based on accessibility and willingness of the owners. Totally 210 lactating cows were randomly selected for Clinical examination and the subsequent CMT screening from the seven farms after proportional allocation of various sample of cows based on the size of farms.

\section{Study Methodology}

Different potential risk factors are considered in the study including breed, age, body condition, udder and teat condition i.e. injuries or blindness, lactation stage, parity, housing conditions, hygienic practice i.e. milker, udder and barn hygiene, and history of antimicrobial treatment in which all information were collected through questionnaire survey, observation and farm records. Before 
CMT screening for SCM examination of udder and teat was employed. As result, among 210 sampled cows' 60 of them were excluded from the study due to clinical mastitis. Then those CMT positive cows were considered for further bacteriological examination to check the presence of CPS.

\section{Clinical examination of the udder and teats}

The udder was first examined visually and then through palpation to detect possible fibrosis, inflammatory swellings, visible injury, atrophied tissue and any other abnormality. The size and consistency of mammary quarters were inspected for the presence of any unusual findings, such as disproportional symmetry, swelling, firmness and blindness. Viscosity and appearance of milk secretion from each mammary quarter were examined for the presence of clots, pus, flakes, blood, and watery secretions (Kivaria et al, 2004). Thus, cows with clinical mastitis and blind teats were not included for further examination.

\section{California mastitis test}

CMT was employed on 150 cows to diagnose the presence of SCM. A squirt of milk from each quarter of the udder was placed in each of the four shallow cups in the CMT paddle and an equal amount of the CMT reagent was mixed to it. Evaluation of the degree of gel formation was done by gently rotation of the CMT paddle and the results were determined based on the degree of gel formation and categorized as negative if there was no gel formation, or positive if there was gel formation ranging from +1 to +3 (Quinn et al., 2002). If at least one quarter was positive, then the cow was considered as SCM patient.

\section{Collection of milk sample}

Milk samples were collected according to Quinn et al., (2002). Milk samples for culture were collected before milking. Hands of the sample collector and quarters of the udder were washed thoroughly and dried. Teats were disinfected with cotton soaked in a $70 \%$ alcohol solution before sampling. Approximately $10 \mathrm{ml}$ of milk was collected aseptically with sterile universal tubes after discarding the first three milking streams. Then sample from each quarter was recorded accordingly and transported in icebox with ice packs to the Microbiology Laboratory of College of Veterinary Medicine, Haramaya University. Up on arrival to the laboratory, the samples were either immediately cultured or stored at $+4^{\circ} \mathrm{C}$ for a maximum of $24 \mathrm{~h}$ until culturing on standard bacteriological media. 


\section{Bacteriological isolation and identification}

Bacteriological examination was done according to the protocols of the (ISO, 2003) and (Quinn et al., 2002). The milk sample was vortexed and a loop full of milk was used for the quadrant streaking method for each quarter on tryptose blood agar base enriched with $7 \%$ sheep blood (Oxoid, UK). Blood agar plates were incubated aerobically at $37^{\circ} \mathrm{C}$ for $24-48 \mathrm{hr}$. The plates were examined for gross colony morphology, pigmentation and hemolytic characteristics. Presumptive pure colonies were selected which appear to be circular, raised, smooth, glistening with a color ranging from grey-white to orange and sub-cultured on mannitol salt agar media (Oxoid, UK) and incubated aerobically at $37^{\circ} \mathrm{C}$ for $24-48 \mathrm{~h}$. The cultured colonies were sub-cultured on nutrient agar (Oxoid, UK) at $37^{\circ} \mathrm{C}$ for 24 $48 \mathrm{~h}$. Characterization of isolated mastitis causing pathogens was done based on the patterns of haemolysis, morphologic features, Gram stain, biochemical test like catalase test and coagulase test. A sample was considered positive for CPS when at least one colony was identified as coagulase positive by the coagulase test.

\section{Antimicrobial Susceptibility test}

It was done by culturing the selected CPS isolates on Mueller Hinton agar media. The isolates were tested for 9 antimicrobials using the Kirby-Bauer disk diffusion method. The antimicrobial disks have various concentrations. Antibiotic discs were applied onto the inoculated MHA using disc dispenser and gently pressed to ensure intimate contact with the surface. The plates were incubated aerobically at $37^{\circ} \mathrm{C}$ for $18-24 \mathrm{~h}$. The zones of inhibition were measured using a ruler and Oxford mathematical set divider. The results were reported as the diameter of the zone surrounding the individual disk in which bacterial growth was absent (CLSI, 2007). Based on this, the isolates were defined as resistant, intermediate and susceptible.

\section{Data analysis}

The data of questionnaire, observation and laboratory results were recorded and analyzed using SPSS version 20. Descriptive statistics was employed to summarize the data including frequency and percentile. The Chi-square test was also undertaken to demonstrate the statistical association between SCM positive cases and potential risk factors. Furthermore, multi-collinearity between the independent variables was checked by linear regression collinearity diagnostics. The association between variables was considered as statistically significant at $P \leq 0.05$. The confidence interval was set at $95 \%$. 


\section{Result}

\section{Prevalence}

From the 210 lactating cows examined 60 (28.57\%) and 150 cows (71.4\%) had clinical and subclinical mastitis, respectively. SCM due to coagulase positive Staphylococcus accounted for $66 \%(99 / 150)$ and $28.5 \%$ (160/562) prevalence at cow and quarter level, respectively (Table 1). Among the total of 600 teats examined, $38(6.3 \%)$ were blind, of these blind teats 13 were from the left front (LF), 13 were from left rear (LR), 5 were from right front (RF) and 7 were from right rear $(\mathrm{RR})$ quarters.

Table 1: Rate of infection due to CPS at quarter level.

\begin{tabular}{lllllll}
\hline Tested quarters & $\begin{array}{l}\text { Total No. } \\
\text { examined }\end{array}$ & $\begin{array}{l}\text { CPS } \\
\text { infected } \\
\text { quarters }\end{array}$ & $\begin{array}{l}\text { Prevalence } \\
(\%)\end{array}$ & $\mathrm{X}^{2}$ & P-value CI \\
\hline Left Front (LF) & 137 & 39 & 24.38 & 1.023 & 0.796 & $95 \%$ \\
Left Rear (LR) & 137 & 42 & 26.25 & & & \\
Right Front (RF) & 145 & 36 & 22.5 & & \\
Right Rear (RR) & 143 & 43 & 26.88 & & \\
Totally & 562 & 160 & $28.5 \%(160 / 562)$ & & \\
\hline
\end{tabular}

\section{Questionnaire survey and observation}

In the present study parity, stage of lactation, udder injuries, age, breeds and house hygiene had significant association $(P<0.05)$ with the prevalence of subclinical mastitis due to CPS (Table 2). Cross breed cows are more affected than local $(P<0.05)$. Lactating cows with above 8 years age is highly infected with CPS, while those at the age interval of $5-8$ years is less susceptible to CPS $(P<0.05)$, likewise prevalence of CPS was significantly high in cows with parity number more than 5 and less in those with parity1 up to $3(P<0.05)$. Unlike early stage lactation, cows in late stage lactation Cows suffered most from CPS $(P<0.05)$. Infection rate is high in cows with injured udder/teat $(P$ $<0.05)$. Cows which are managed in poor house condition showed significantly high CPS prevalence $(P<0.05)$. However, milkers hand hygiene, udder hygiene and common towel used for drying teat did not show statistically significant ( $P$ $>0.05$ ) variations (Table 2 ). 
Table 2: Prevalence of subclinical mastitis due to CPS with different potential risk factors.

\begin{tabular}{|c|c|c|c|c|c|}
\hline Risk factor & $\begin{array}{l}\text { Total No. } \\
\text { Examined }\end{array}$ & $\begin{array}{l}\text { No of } \\
\text { Positive } \\
\text { Prevalence } \\
(\%)\end{array}$ & $x^{2}$ & P-value & $\begin{array}{l}\text { Confidence } \\
\text { Interval } \\
\text { (CI) }\end{array}$ \\
\hline \multicolumn{6}{|l|}{ Breed } \\
\hline Cross & 104 & $74(71.2 \%)$ & $4.014 \mathrm{a}$ & 0.045 & $95 \%$ \\
\hline Local & 46 & $25(54.3 \%)$ & & & \\
\hline \multicolumn{6}{|l|}{ Age } \\
\hline $3-5$ years & 50 & $35(70 \%)$ & $18.773 \mathrm{a}$ & 0.000 & \\
\hline $6-8$ years & 76 & $40(52.6 \%)$ & & & \\
\hline$>8$ years & 24 & $24(100 \%)$ & & & \\
\hline \multicolumn{6}{|l|}{ Lactation stage } \\
\hline $1-3$ months & 58 & $31(53.4 \%)$ & $15.171 \mathrm{a}$ & 0.001 & \\
\hline 4-5 months & 65 & $42(64.6 \%)$ & & & \\
\hline$>5$ months & 27 & $26(96.3 \%)$ & & & \\
\hline \multicolumn{6}{|l|}{ Parity } \\
\hline $1-3$ births & 85 & $48(56.5 \%)$ & $10.098 \mathrm{a}$ & 0.006 & \\
\hline 4-5 births & 56 & $42(75 \%)$ & & & \\
\hline Over 5 births & 9 & $9(100 \%)$ & & & \\
\hline \multicolumn{6}{|c|}{ Udder/teat condition } \\
\hline Not injured & 123 & $73(59.3 \%)$ & $13.468 \mathrm{a}$ & 0.000 & \\
\hline Injured & 27 & $26(96.3 \%)$ & & & \\
\hline \multicolumn{6}{|l|}{ Udder hygiene } \\
\hline Poor hygiene & 75 & $54(72 \%)$ & $2.046 \mathrm{a}$ & 0.121 & \\
\hline Good hygiene & 75 & $45(60 \%)$ & & & \\
\hline \multicolumn{6}{|c|}{$\begin{array}{l}\text { Hand hygiene before } \\
\text { milking }\end{array}$} \\
\hline Washed & 72 & $42(58.3 \%)$ & $3.627 \mathrm{a}$ & 0.057 & \\
\hline Not washed & 78 & $57(73.1 \%)$ & & & \\
\hline \multicolumn{6}{|l|}{ Usage of towel } \\
\hline Common towel & 39 & $28(71.8 \%)$ & $0.789 \mathrm{a}$ & 0.375 & \\
\hline No use of towel & 111 & $71(64 \%)$ & & & \\
\hline \multicolumn{6}{|l|}{ House hygiene } \\
\hline Good & 70 & $33(47.1 \%)$ & $20.798 \mathrm{a}$ & 0.000 & \\
\hline Poor & 80 & $66(82.5 \%)$ & & & \\
\hline
\end{tabular}




\section{Antimicrobial susceptibility pattern}

From the total $160 \mathrm{CPS}$ isolates, antimicrobial susceptibility tests were conducted on 81 randomly selected isolates. CPS isolates were found to be relatively susceptible to chloramphenicol (63.0\%) followed by gentamycin (46.9\%) and kanamycin (42.0\%) (Table 4). However, there was high multi-drug resistance of $71(87.6 \%)$, among the CPS isolates (Table 3). In addition, high drug resistance encountered against some commonly used drugs including ampicillin (90.1\%) penicillin (67.9\%) and Tetracycline (54.3\%) (Table 4).

Table 3: Multidrug Resistance pattern of CPS isolates.

\begin{tabular}{llll}
\hline Level of Resistance & $\begin{array}{l}\text { No of CPS } \\
\text { isolate }\end{array}$ & Percent (\%) $\begin{array}{l}\text { Cumulative } \\
\text { Multidrug Resistance, } \\
\text { No (\%) }\end{array}$ \\
\hline No resistance & 1 & $1.2 \%$ & - \\
Resistance for 1 drug & 9 & $11.1 \%$ & - \\
Resistance for 2 drugs & 21 & $25.9 \%$ & $21(25.9 \%)$ \\
Resistance for 3 drugs & 11 & $13.6 \%$ & $32(39.5 \%)$ \\
Resistance for 4 drugs & 24 & $29.6 \%$ & $56(69.1 \%)$ \\
Resistance for 5 drugs & 10 & $12.3 \%$ & $66(81.4 \%)$ \\
Resistance for 6 drugs & 5 & $6.2 \%$ & $71(87.6 \%)$ \\
Total & 81 & $100 \%$ & $71(87.6 \%)$ \\
\hline
\end{tabular}

Table 4: Antibiotic susceptibility pattern of CPS isolate from subclinical mastitic cows.

\begin{tabular}{llll}
\hline Antimicrobials & $\begin{array}{l}\text { Resistant } \\
\text { No (\%) }\end{array}$ & $\begin{array}{l}\text { Intermediate } \\
\text { No (\%) }\end{array}$ & $\begin{array}{l}\text { Susceptible } \\
\text { No (\%) }\end{array}$ \\
\hline Amoxicillin & $24(29.6)$ & $51(63.0)$ & $6(7.4)$ \\
Gentamycin & $1(1.2)$ & $42(51.9)$ & $38(46.9)$ \\
Streptomycin & $29(35.8)$ & $49(60.5)$ & $3(3.7)$ \\
Penicillin & $55(67.9)$ & $25(30.9)$ & $1(1.2)$ \\
Chloramphenicol & $0(0.0)$ & $30(37.0)$ & $51(63.0)$ \\
Kanamycin & $3(3.7)$ & $44(54.3)$ & $34(42.0)$ \\
Ampicillin & $73(90.1)$ & $4(4.9)$ & $4(4.9)$ \\
Tetracycline & $44(54.3)$ & $34(42.0)$ & $3(3.7)$ \\
Erythromycin & $32(39.5)$ & $46(56.8)$ & $3(3.7)$ \\
\hline
\end{tabular}




\section{Discussion}

The $71.4 \%$ subclinical mastitis prevalence of the present study is close to the work of Ararsa Duguma et al (2014). However, it is greater than the reports of Mesele Abera et al, 2013 and Rigbe Haftu et al., 2012 who reported 36.7 $\%$ and $33.8 \%$ of SCM, respectively. This study revealed the prevalence of SCM due to CPS at cows' level (66\%) and quarter's level (28.46\%), similarly Oudessa and Tareke (2003), report relatively lower prevalence of CPS as a cause of SCM in the country. The high prevalence of CPS might be associated with its ability to colonize teats frequently, its existence in intracellular and localize within micro abscesses in the udder and hence resistant to antibiotic treatment (MacDonald, 1997). Variation in the rate of CPS infection among different areas across the country could be due to the difference in management practices, hygienic status and the breed composition.

Prevalence of SCM due to CPS was significantly higher $(\mathrm{P}<0.05)$ in cross breed cows than the local breeds which is also true in the work of Mulugeta Yohannis and Wassie Molla (2013) who reported high prevalence of mastitis in Jersey breed than local zebu cattle. This could be due to anatomically large pendulous udder of cross breed cows which can be easily exposed to environmental injuries which in turn predispose cows to suffer from mastitis. Age wise the present study indicate significantly $(P<0.05)$ higher CPS infection at advanced age which is in agreement with the finding of Rigbe Haftu et al., (2012). This is probably due to prolonged period of exposure to the infecting organisms and predisposing factors like stress of lactation which favor dilation of teat canal due to repeat milking thereby facilitating the entry of pathogens into the teat canal to cause subclinical intramammary infection (Shittu et al., 2012).

In this study, prevalence of SCM was significantly higher $(P<0.05)$ in late lactation as compared to early and mid lactation, like wise Kassaye Getahun et al., (2008) and Rigbe Haftu et al., (2012) states that increased prevalence of mastitis was encountered as lactation stage advance. On the contrary, Oudessa Kerro and Fiseha Tareke (2003) and Mulugeta Yohannis and Wassie Molla (2013) reported that cows at early stage of lactation are more susceptible to mastitis. This study revealed significantly $(P<0.05)$ higher prevalence of CPS as parity number increased. Similar findings were previously reported by (Oudessa Kerro and Fiseha Tareke, 2003; Mungube et al., 2005; Demelash Biffa et al., 2005; Kassaye Getahun et al., 2008; Mulugeta Yohannis and Wassie Molla, 2013). The age-multiparous-high prevalence relationship 
is explored to be due to decrease in teat patency, degree and frequency of previous exposure in multiparous old cows (Radostits et al., 2007). In addition, teat and udder injuries has shown significantly $(P<0.05)$ higher prevalence of CPS (96.3\%), which are caused by barbed wire fences, tick infestations and vigorous suckling calves. High level of CPS in injured udder/teat could be due to favorable environment of the wound (injuries) which ultimately leads to secondary bacterial complication.

On the other hands, House hygiene had shown significant $(P<0.05)$ effect on the prevalence of CPS. In the case of good house hygiene the prevalence were $47.1 \%$, while cows managed in poor house hygiene had prevalence of $82.5 \%$. In dairy managed under unhygienic houses, manure and wet bedding materials were not frequently removed which in turn favour high occurrence of CPS. This is consistent with the findings of earlier works in Ethiopia that implicated poor barn hygiene to high prevalence of mastitis (Hunderra Sori et al., 2005; Mesele Abera et al., 2013, Mulugeta Yohannis and Wassie Molla, 2013).

The present study has demonstrated the presence of high level of multi drug resistance 71 (87.6\%), especially among commonly used drugs like penicillin and tetracycline. The $67.9 \%$ of SCP isolates were resistance to penicillin in this study, likewise Firaol Tamiru et al, (2013), Zerfie Taddesse et al (2014) and Mesele Abera et al, (2013) reported 50\%, $90 \%$ and $94.4 \%$ Staphylococcus aures resistance, respectively. There was also $54.3 \%$ resistance among the CPS isolate against tetracycline in this study, likewise Berhanu Andualem, (2009) stated $65.3 \%$ resistance of Staphylococcus aures against tetracycline. Chloramphenicol was the most effective drug with $63 \%$ CPS isolates susceptibility in the present study, similarly Rigbe Haftu et al, (2012) and Mesele Abera et al, 2013 indicate Staphylococcus aures susceptibility of $58.8 \%$ and $100 \%$ for Chloramphenicol, respectively. According to the present study, Gentamicin is the second effective drug with 48.9 susceptibility of CPS. Similarly, Firaol Tamiru et al, (2013) and Zerfie Taddesse et al (2014) report $71.4 \%$ and $84.3 \%$ susceptibility of Staphylococcus aures to Gentamicin, respectively.

In the current study area there is frequent, prolonged and indiscriminate use of antimicrobial drugs. In addition, there is a growing believe that some of the drugs which have been used in the study area were not introduced in to the country legally after assessment of their quality standard. In fact, it is not uncommon to find these drugs in the hand of farmers which have been bought from illegal outlet which adds up to the conclusion that most of CPS isolates 
showed resistance to commonly used antimicrobials due to the mentioned facts. The high prevalence of CPS infection detected in dairy cows has public health concern since CPS bacteria's are capable of producing heat-stable enterotoxins, which might cause staphylococcal food poisoning outbreaks when ingested by humans in sufficient quantities (Lamprell et al., 2004). Therefore, Good hygienic management practices, regular monitoring of antimicrobial resistance and further research to identify species and strains of CPS has paramount significance to reduce and prevent the pathogen effect on dairy industry.

\section{References}

Andualem, B., 2009. The isolation rate of Staphylococcus and Streptococcus pathogenic isolates and their antimicrobial responses in Northwest Ethiopia. Ethiop. J. Biol. Sci., 8:1, 1-14.

MacDonald, 1997. Streptococcal and Staphylococcal mastitis in U.S. J. Am. Vet. med. Assoc., 170:1157.

Abera, M., Demie, B., Aragaw. K., Regassa, F., and Regassa, A., 2013. Isolation and identification of Staphylococcus aureus from bovine mastitic milk and their drug resistance patterns in Adama town, Ethiopia. Afr. J. Dairy Farming Milk Prod., 1:2, 019-023.

Basappa, B.K., Sadashiv, S.O., Mahantesh, M.K., and Rajeshwari, D.S., 2011. Prevalence and Antimicrobial Susceptibility of Coagulase Negative Staphylococci isolated from Bovine Mastitis. Vet world., 4:4, 158-161.

Biffa, D., Debela, E., Beyen, F., and Wolde, M., 2005. Factors Associated with Bovine Udder infection in Small holder Dairy farms in Ethiopia. Bulletin of Animal Health and production in Africa., 53, 248-264.

CLSI (Clinical and Laboratory Standards Institute)., 2007. Performance Standards for Antimicrobial Susceptibility Testing; Seventeenth Informational Supplement. An Informational Supplement for Global application Developed through the Clinical and Laboratory Standards Institute consensus process Document M100-S17, 27.

Duguma, A., Tolosa,T., and Yohannes, A., 2014. Prevalence of clinical and sub-clinical mastitis on cross bred dairy cows at Holleta Agricultural Research Center, Central Ethiopia. J. Vet. Med. Anim. Health., 6, 1, 13-17.

Getahun, K., Kelay, B., Bekana, M., and, Lobago F., 2008. Bovine mastitis and antibiotic resistance patterns in Selalle smallholder dairy farms, central Ethiopia. Trop Anim Health Prod., 40, 261-268. 
HADB (Haramaya woreda Agricultural Development Bureau). 2009. Haramaya, Ethiopia.

Haftu, R., Taddele, H., Gugsa, G., and Kalayou, S., 2012. Prevalence, bacterial causes, and antimicrobial susceptibility profile of mastitis isolates from cows in large-scale dairy farms of Northern Ethiopia. Trop Anim Health Prod., 44, 1765-71.

ISO, 2003. Microbiology of food and animal feeding stuffs - Horizontal method for the detection and identification of Staphylococci., 3: 3-6888, Geneva, Switzerland.

Kerro, O., and Tareke, F., 2003. Bovine mastitis in selected areas of southern Ethiopia. Trop Anim Health Prod., 35, 197-205.

Kivaria, F.M., Noordhuizen, J.P.T.M., and Msami, H.M., 2004. Risk factors associated with the incidence rate of clinical mastitis in smallholder dairy cows in the Dares Salaam region of Tanzania. Trop Anim Health Prod., 173, 623-629.

Lamprell, H., Villard, L., Chamba, J., Beuvier, E., Borges, E., Maurin, F., Mazerolles, G., Noel, Y., and Kodjo, A., 2004. Identification and biotyping of coagulase-positive staphylococci (CPS) in ripened French raw milk cheeses and their in vitro ability to produce enterotoxins. Revue Méd. Vét., 155: 92-96.

Leitner G, Merin, U. and Silanikove, N., 2011. Effects of glandular bacterial infection and stage of lactation on milk clotting parameters: Comparison among cows, goats and sheep. Int Dairy J., 21, 279-285.

Mungube,E O., Tenhagen, B A., Regassa, F. , Kyule, M N., Shiferaw, Y., Kassa, T., and Baumann M P., 2005. Reduced milk production in udder quarters with subclinical mastitis and associated economic losses in crossbred dairy cows in Ethiopia. Trop Anim Health Prod., 37, 503-512.

Quinn PJ, Carter ME, Markey, B. and Carter GR., 2002. Clinical Veterinary Microbiology, Wilfe Publishing, London., pp. 95-101.

Radostits, O M., Gay, C C., Blood, D C. and Hinchllif, KW., 2007. Mastitis. In Veterinary Medecine $9^{\text {th }}$ ed., Haracourt L td. London., pp. 174- 758.

Ranjan, R., Gupta, K.M. and Singh, K.K.., 2011. Study of bovine mastitis in different climatic conditions in Jharkh and, India. Vet world., 4:5, 205-208.

Sharif, A., Umer, M. and Muhammad, G., 2009. Mastitis control in dairy production. $J$ Agric Soc Sci., 5, 102-105.

Shittu, A, Abdullahi, J., Jibril , A, Mohammed ,AA., and Fasina, FO., 2012. Subclinical mastitis and associated risk factors on lactating cows in the Savannah Region of Nigeria. BMC Vet Res., 8, 134-141.

Sori, H., Zerihun, A. and Abdicho, S., 2005. Dairy cattle Mastitis In and Around Sebeta, Ethiopia. Inter. J. Appl. Res. Vet. Med.,. 3, 332-38. 
Taddesse, Z., Tiruneh, M., and Gizachew, M., 2014. Staphylococcus aureus and its Antimicrobial Susceptibility Pattern in Patients, Nasalcarage of Health Personnel, and objects at Dessie referral hospital, Northern Ethiopia. GJMR-C Micro and Path., 14:2, 29-35.

Tamiru, F., Alemu, S., and Tsega, A., 2013. Aerobic Microorganisms Isolated from Mastitic Bovine Milk and their Antimicrobial Susceptibility Profile, Ethiopia. AmEuras. J. Agric. and Environ. Sci., 13:7, 920-925.

Yohannis, M. and Molla, W., 2013. Prevalence, risk factors and major bacterial causes of bovine mastitis in and around Wolaita Sodo, southern Ethiopia. Afr. J. Microbiol. Res., 7, 5400-5405. 